\title{
Moxidectin Interference on Motor Activity of Rats
}

\author{
Patrícia de Sá e Benevides Rodrigues-Alves ${ }^{1}$, Jorge Camilo Flório ${ }^{2}$, Ivo Lebrun ${ }^{3}$, Maria \\ Martha Bernardi ${ }^{2}$ and Helenice de Souza Spinosa ${ }^{2}$ \\ ${ }^{1}$ Instituto de Psicologia; Universidade de São Paulo; SP - Brasil. ${ }^{2}$ Departamento de Patologia, Faculdade de \\ Medicina Veterinária e Zootecnia; Universidade de São Paulo; Av. Prof. Dr. Orlando Marques de Paiva, 87; \\ 05508-900; São Paulo - SP - Brasil. ${ }^{3}$ Instituto Butantan - SP - Brasil
}

\begin{abstract}
The present study investigated the effects of the moxidectin (MXD) in some parameters of rat motor function and neurochemical. The general activity in the open field and the motor coordination in the wooden beam were employed to evaluate the MXD effects. The results showed that, in the open field, even at high doses (2.0 and 20.0 $\mathrm{mg} / \mathrm{kg}$ ), the MXD did not alter the locomotion and the rearing frequencies. However, MXD was able to impair the motor coordination of the animals at wooden beam. Neurochemical studies of striatal GABA and dopamine neurotransmitters showed a reduced levels of dopamine and its metabolite, homovanillic acid, without interference on striatal GABA levels. Since GABAergic receptor stimulation had an inhibitory effect on dopaminergic striatal system, the decreased motor coordination could be attributed to an action of MXD on dopamine system via GABA activation.
\end{abstract}

Key words: Moxidectin, GABA, motor coordination, rat, open field, wooden beam

\section{INTRODUCTION}

Moxidectin (MXD) is a milbemycin compound produced by a combination of fermentation and chemicals synthesis. MXD is obtained by chemical modification of nemadectin, the natural compound is produced when Streptomyces cianogriseus is ground under controlled culture conditions (Takigushi et al., 1980). The milbemycins were discovered in 1973, as acaricidal and insecticidal compounds for crop protection by Sankyo scientists and their name reflected this (milbe mite + myc fungus + in pharmaceutical product) (Campbell, 1989; Steel, 1993; Shoop et al.,1995; Lanusse et al. 1997). The mylbemicins anthelmintics have a broad-spectrum activity against internal and external parasites in animals.
MDX is a milbemycin endectocide compound active at extremely low dosages against a wide variety of nematode and arthropod parasites of domestic animals (Campbell, 1989; Lifschitz et al., 2002; Njue et al., 2004).

Milbemicyn and avermectins (AVM) are highly lipophilic substances that dissolve in most organic solvents, and MXD solubility in water is $4.3 \mathrm{mg} / \mathrm{L}$. Their high lipophilicity accounts for a wide tissue distribution and long residence in plasma, and allows these substances to cross the cellular barriers (Lanusse et al., 1997). After treatment, this drug is found mainly in liver and fat (Molento et al., 2004).

MXD peak plasma concentration $\left(\mathrm{C}_{\max }\right)$ were achieved $8 \mathrm{~h}$ post-treatment (subcutaneous administration of $200 \mu \mathrm{g} / \mathrm{kg}$ to cattle), and the

\footnotetext{
*Author for correspondence: hspinosa@usp.br
} 
concentration of MXD in fat after 28 days of treatment in cattle has been shown to be ninetyfold higher than that detected in plasma. A great proportion of MXD parent drug would accumulate in fat, such phenomenon explaining the long plasma residence time obtained for this drug, after an early peak concentration followed by a fast decline (distribution phase) in the plasma concentration profile between the $\mathrm{C}_{\max }$ and 10 days post-treatment (Lanusse et al., 1997). When administered orally to ovine and rats, this peak will be of 10 hours (Joint FAO/WHO, 1995).

MXD showed moderate toxicity when administered orally to rats and mice $(50 \%$ lethal dose (LD 50) 50-100 mg/kg (Joint FAO/WHO, 1995). When MXD is administered to the animals in high doses, the adverse effects observed are characterized by neurotoxicity signs as depression, ataxia, tremors, anxiety, vision difficulty, coma and death.

Although the antiparasitic activity of the milbemycins has been described since more than two decades, its mechanism of action is still not totally elucidated. The main difficulty is due to controversial studies performed in different biological systems with different methodologies, which provides inconclusive data. In this respect, studies about the AVM's mechanism of action are more abundant than those of the milbemycins. The molecular structures of the two groups of so-called 'endectocide' compounds are superimposable (Shoop et al., 1995). They share some structural and physicochemical properties, and their broadspectrum antiparasitic activity against nematodes and arthropods at extremely low dosage rates (Steel, 1993) is based on a common mode of action (Shoop et al., 1995; Lanusse et al., 1997; Fisher and Mrozik, 1989; Turner and Schaeffer; 1989; Arena et al., 1991, 1992, and 1995; Roder, 1998; Spinosa et al., 1999 and 2002; Forrester et al., 2002).

MXD and ivermectin are believed to act by binding to glutamate- and gamma-aminobutyric acid (GABA)-gated chloride channels, resulting in somatic and pharyngeal muscle paralysis of the parasite, respectively (Duce and Scott, 1985; Dawson et al., 2000; Feng et al., 2002; Lifschitz et al, 2002; Molento et al.,2004; Njue et al, 2004). In the insects and arthropods, the AVMs interfere at the transmission among nervous and muscular cells, because the GABAergic receptors are located at the neuromuscular junction. These inhibitory receptors are found only in invertebrates (insects, crustaceans and nematodes) and belong to the superfamily of ligand-gated ion channels (Arena, 1994; Cleland, 1996; Cully et al., 1996; Njue et al., 2004). AVMs also interact with GABA receptors in brain of vertebrates (mammals), but its affinity for the invertebrate animals receptor is approximately 100 times greater (Schaeffer and Haines, 1989).

Thus, most of the studies accomplished on the mechanism of action of the macrocyclic lactones in mammals involve the GABA neurotransmitter, since this neurotransmitter has an important role in the regulation of the motor activity (Agmo and Giordano, 1985; Tegnér et al., 1993; Kriem et al., 1998). The goal of the current study was to evaluate the possible effects of the MXD in the general activity of rats observed in the open field and in their motor coordination at the wooden beam. Also, neurochemical analysis of striatal GABA and dopamine neurotransmitters were performed.

\section{MATERIAL AND METHODS}

\section{Animals}

Male Wistar rats, weighing 180-370 g, which come from local colony, were used. Seven days before the experiments, the animals were housed, in number of five, in plastic cages with metallic cover $(40 \times 50 \times 20 \mathrm{~cm})$ at a controlled room temperature $\left(22 \pm 2^{\circ} \mathrm{C}\right)$, with a $12 \mathrm{~h}$ light-dark cycle (the lights came on at 07:00). Water and food were available ad libitum. The animals were randomly divided into control and experimental groups. Behavioral tests on control and experimental rats were intermixed in order to minimizing circadian changes. All the observations were made between 08:00 and 18:00. The animals used in this study were maintained in accordance with the guidelines of the Committee on Care and Use of Laboratory Animal Resources, National Research Council, USA.

\section{Drugs}

Moxidectin (Cydectin - Fort Dodge Animal Health Ltd., Campinas) was diluted in sweet almond oil (Industrial Leclerc Ltd., São Paulo), obtaining the concentrations of $0.2,2.0$ and $20 \mathrm{mg} / \mathrm{ml}$, just before subcutaneous (SC) injections of $1.0 \mathrm{ml} / \mathrm{kg}$ from one of these preparations.

The lowest MXD dose employed was $0.2 \mathrm{mg} / \mathrm{kg}$, i.e., a therapeutic dose widely used clinically in 
different animal species; the remaining doses, i.e., 2.0 and $20.0 \mathrm{mg} / \mathrm{kg}$ were increased in a logarithmic scale.

\section{Open Field}

Sixty four male rats were divided into four groups: three experimental $(\mathrm{n}=16$ for each group; 0.2, 2.0 or $20.0 \mathrm{mg} / \mathrm{kg}$ of MXD) and one control ( $\mathrm{n}=16$; $1.0 \mathrm{ml} / \mathrm{kg}$ sweet almond oil), and tested in an open field. The open field apparatus was a round wooden arena, $970 \mathrm{~mm}$ in diameter and metallic wall, $280 \mathrm{~mm}$ of height, painted white, with the floor divided into 25 areas almost equal, delineated in black. During the experiment, three $40 \mathrm{~W}$ white bulbs hanging $720 \mathrm{~mm}$ from the floor provided continuous illumination of the arena. Hand-operated counters were employed to score locomotion (number of floor areas entered) and rearing frequencies (number of times that an animal stood on its hind legs) and a chronometer was used to measure the duration of immobility (total time without spontaneous movements). For open field observations, each rat was individually placed in the center of arena and its behavioral parameters were recorded over $3 \mathrm{~min}$ at 24 and 72 $\mathrm{h}$ after the treatment. The rats returned to their home cage immediately after the observations. The animals of the control and experimental groups were observed at random. The open field apparatus was washed with a 5\% ethanol solution before introduction of each animal in the arena, in order to eliminate any possible influences of smell left by previous subjects.

\section{Wooden Beam}

The motor coordination was evaluated through a new model, the wooden beam. This model was adapted from the one described by Jeffery and Blakemore (1997). The apparatus was a wooden beam, $18 \mathrm{~mm}$ in width and thickness and $2 \mathrm{~m}$ in length, with a $100 \mathrm{~mm}^{2}$ and $18 \mathrm{~mm}$ in thickness platform in each extremity. The beam had a 200 $\mathrm{mm}$ height feet, at platforms and at center, painted white with two black vertical marks delimiting $1 \mathrm{~m}$ in the central portion (Fig. 1). During the experiment, this beam was leaning on a balcony of the observation room. Thirty rats were used in the wooden beam test, divided in three experimental groups ( $\mathrm{n}=10$ for each group; $0.2,2.0$ or 20.0 $\mathrm{mg} / \mathrm{kg}$ of MXD). Initially, each rat was trained to walk on the beam, in 5 min daily sessions, in the following way: on the first day, positive reinforcement (small portion of condensed milk) was put on both platforms and, following, the rat was introduced to get used to the environment and to the reinforcement. Next day, the animal was put at beam, close to the platform with the reinforcement, with the head turned back to this. On the following days, the rat was put at beam, however, at more and more distant from the platform with reinforcement, until the animal crossed the beam, reaching the opposite platform and returned to the initial platform, always receiving the reinforcement at the end of each crossing. The training period (7 to 10 days) was considered complete when each rat could reliably cross the beam without stalling (four crossings), few footstep errors were made at this stage. The animals that were not capable to walk in the beam in 10 days were eliminated from the experiment. Once trained, the rats were submitted to three observation sessions $(24 \mathrm{~h}$ before and $24,72 \mathrm{~h}$ after the treatment). During each evaluation, a score (Table 1) was attributed for each step with the pelvic member, turned for the observer, when the rat walked in the central portion of beam $(1 \mathrm{~m}$ among the vertical marks) at each cross. At the end of each session, the scores obtained by each animal in the four crossings were added. Before each animal was tested, the wooden beam was cleaned with a cloth moistened in water and after that all the animals of each cage, with $5 \%$ ethanol solution.

Table 1 - Scores for the evaluation of the rat behavior at wooden beam (Jeffery and Blakemore, 1997).

\begin{tabular}{ll}
\hline Score & Foot Position \\
\hline 0 & Normal: foot positioned on top of beam, no slippage \\
1 & Minor error: foot slip so that part of the foot was visible below the lower surface of beam \\
2 & Major error: whole foot slipped below the lower surface of the beam \\
\hline
\end{tabular}


Determination of striatal neurotransmitters and metabolite levels

Eighteen male rats were divided into two groups: the experimental $(\mathrm{n}=9)$ received $0.2 \mathrm{mg} / \mathrm{kg}$ of MOX) and the control $(\mathrm{n}=9) 1.0 \mathrm{ml} / \mathrm{kg}$ sweet almond oil). Rats treated with as without MOX were decapitated $72 \mathrm{~h}$ after the treatments. Brains were dissected on dry ice and prepared as described previously (Felicio et al., 1996). Briefly, the striatum was weighted and stored $-70{ }^{\circ} \mathrm{C}$. During the weeks following the sample collection, perchloric acid was added to the tissues, which were then homogenized by sonication one week before the neurochemical evaluations. Dopamine
(DA) and its metabolites, homovanillic acid (HVA) and 3,4 dihydroxyphenylacetic acid (DOPAC) were measured by HPLC (Shimadzu, model 6A) with a C-1 column (Shimpak-ODS), an electrochemical detector (Shimadzu, model 6A), a sample injector (valve for $20 \mu \mathrm{l}$ ), and an integrator (Shimadzu, model $6^{\mathrm{A}}$ Chromatopac). GABA was measured by HPLC (HP, model 1100) with a Beckman $5 \mu$ Ultrasphere ODS-PTH column, a sample injector (valve for $1.0 \mathrm{ml}$ ). Each sample was run for 25 min to DA and its metabolites and $28 \mathrm{~min}$ to GABA. The limit of detection was $2 \mathrm{pg}$ for DA, DOPAC and $20 \mathrm{pg}$ for HVA and GABA.

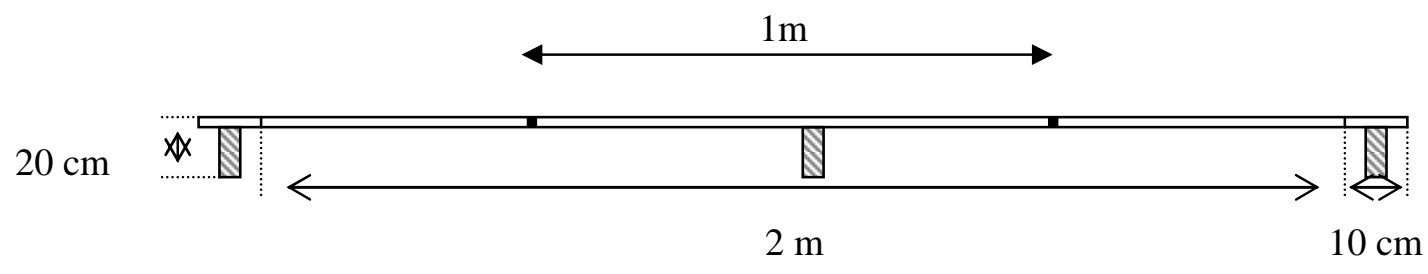

(A)

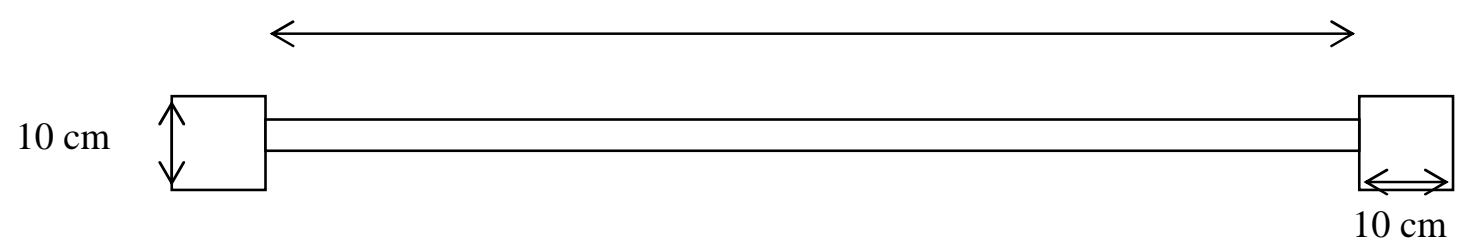

(B)

Figure1 - Scheme of wooden beam (thickness = $18 \mathrm{~mm}$ ). (A) Lateral view and (B) superior view.

\section{Statistical Analysis}

The Bartlett test was used to evaluate the data homocedasticity. Analysis of variance (ANOVA), followed by Tukey-Kramer multiple comparisons test, was used to analyze the data from the open field test. The Friedman test for repeated measures, followed by the Dunn test for multiple comparisons was employed to the data from wooden beam test. The neurochemical data were analyzed by Mann-Whitney-U-test. In these experiments, $\mathrm{p}<0.05$ was the criterion for statistical significance.

\section{RESULTS}

Fig. 2 shows the effects of the administration of the MXD in the general activity of rats observed in the open field. Although $\mathrm{GABA}_{\mathrm{B}}$ receptor agonist (baclofen) inhibited dose-dependently the locomotor activity (Agmo and Giordano, 1985; Nissbrandt and Engberg, 1996; Paredes et al., 1997), in the current experiment, the ANOVA did not show significant differences in the locomotion frequencies $(\mathrm{F} 24=0.90 ; \quad \mathrm{F} 72=0.29 ; \quad \mathrm{df}=3 / 63$, $\mathrm{p}>0.05)$ and rearing frequencies ( $\mathrm{F} 24=0.94$; $\mathrm{F} 72=1.79 ; \mathrm{df}=3 / 63, \mathrm{p}>0.05)$ among control and experimental groups. On the other hand, significant differences among the groups were observed in the immobility duration when the rats were observed after $72 \mathrm{~h}(\mathrm{~F} 24=1.79 ; \mathrm{F} 72=5.23$; $\mathrm{df}=3 / 63, \mathrm{p}<0.05)$; the Tukey-Kramer test showed reduction in the duration of immobility of the animals that received 0.2 or $20 \mathrm{mg} / \mathrm{kg}$ of MXD, at the $72 \mathrm{~h}$ post-treatment, when compared to the animals of the control group. 
Although MXD did not show significant effects on the locomotion frequencies, this was able to impair motor coordination of rats evaluated at the wooden beam (Fig. 3). Significant differences were observed in the sum of the scores of the rats that received $0.2 \mathrm{mg} / \mathrm{kg} \quad(\mathrm{Fr}=16.632, \mathrm{p}<0.05), 2.0$ $\mathrm{mg} / \mathrm{kg} \quad(\mathrm{Fr}=16.800, \quad \mathrm{p}<0.05)$ and $20 \quad \mathrm{mg} / \mathrm{kg}$ $(\mathrm{Fr}=15.842, \mathrm{p}<0.05)$ of MXD. The Dunn test of multiple comparisons showed that there was an increase in the sum of the scores after 24 and $72 \mathrm{~h}$ of the administration of the different doses of the drug, when compared to the sum of the scores obtained $24 \mathrm{~h}$ before the injection. At this time (base line), after the training, almost all rats were able to cross the beam with no error.

Table 2 shows the effects of MXD on striatal GABA, dopamine and its metabolite levels. MXD treatment reduced the striatal dopamine and HVA levels. No differences were observed between MXD and controls in striatal GABAergic and DOPAC levels as well as in HVA/DA and DOPAC/DA ratios.

\section{DISCUSSION}

The behavioral observations were accomplished 24 and $72 \mathrm{~h}$ after the administration of MXD, since post $\mathrm{SC}$ administration its $\mathrm{C}_{\max }$ were achieved $8 \mathrm{~h}$ post-treatment in cattle and had a half-life of $80 \mathrm{~h}$ (Lanusse et al, 1997; Joint FAO/WHO, 1995). MXD showed a long plasma residence time after an early peak concentration, followed by a fast decline (distribution phase) in the plasma concentration profile between the $C_{\max }$ and 10 days post-treatment (Lanusse et al, 1997). In the present work, the possible effects of the MXD in the general activity of the rats observed in the open field were studied. General activity is an index for evaluating behavioral changes induced in animals, not only by physiological and genetic manipulation, but also by toxicological ones. Among the techniques used to assess general activity, open field techniques stand out, making it possible to measure various behavioral parameters, among which are those related to emotional, exploratory and motor behavior.
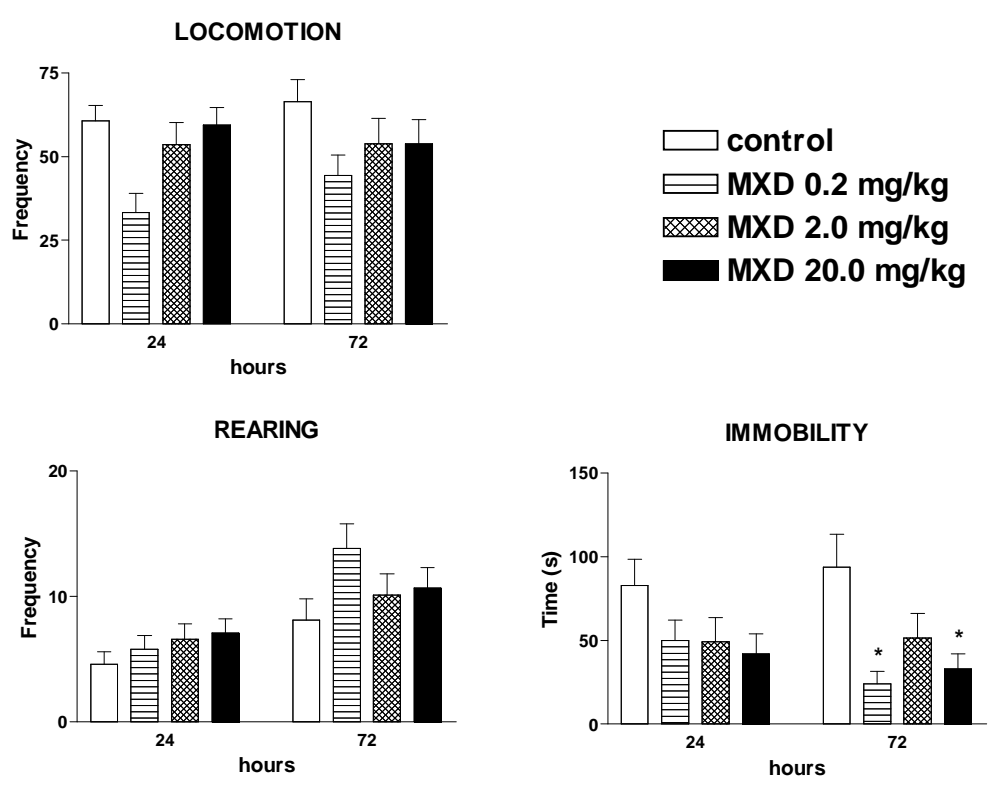

Figure 2 - The effects of moxidectin (MXD) on general activity of rats observed in open field. Data are means \pm standard errors of mean. $* \mathrm{p}<0.05$, ANOVA and Tukey-Kramer (in relation to control group). 
Table 2 - The effects of moxidectin (MXD) on striatal GABA, dopamine and its metabolite levels (ng/g tissue). Animals were treated with $0.2 \mathrm{mg} / \mathrm{kg} \mathrm{MXD}, 72 \mathrm{~h}$. before the assay. Data are means \pm standard errors of mean. $\mathrm{N}=9$ per group.

\begin{tabular}{lcc} 
& \multicolumn{2}{c}{ Groups } \\
\cline { 2 - 3 } & Control & MXD $(0.2 \mathrm{mg} / \mathrm{kg})$ \\
\hline GABA & $905.50 \pm 163.13$ & $778.45 \pm 146.55$ \\
DA & $3,511.90 \pm 638.91$ & $1,537.30 \pm 397.69^{*}$ \\
HVA & $141.24 \pm 24.02$ & $73.20 \pm 17.41^{*}$ \\
DOPAC & $204.66 \pm 39.08$ & $119.04 \pm 28.39$ \\
HVA/DA & $0.040 \pm 0.006$ & $0.058 \pm 0.007$ \\
DOPAC/DA & $0.006 \pm 0.008$ & $0.008 \pm 0.010$
\end{tabular}

*p<0.05, in relation to control group. Mann-Whitney U-test.

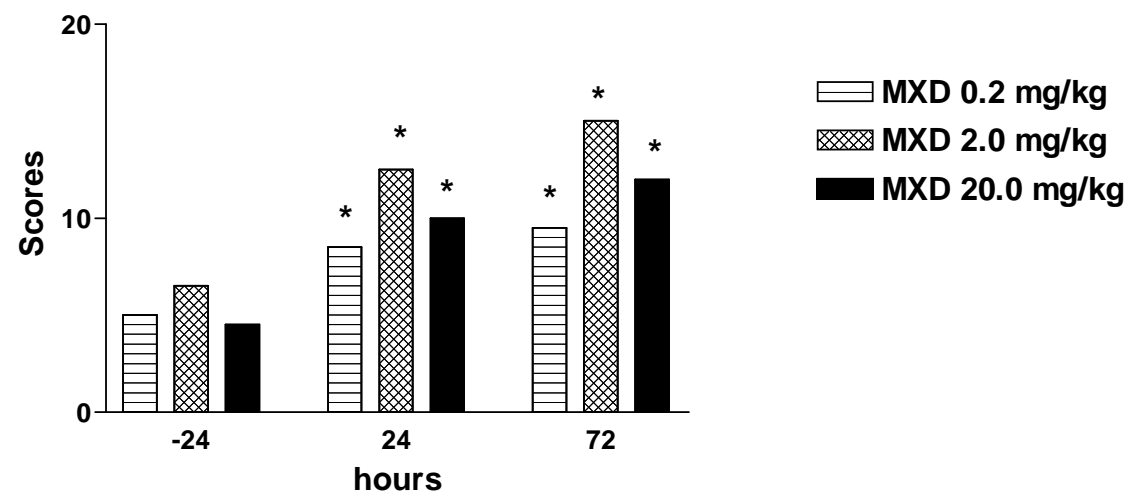

Figure 3 - The effects of moxidectin (MXD) on motor coordination of rats evaluated at wooden beam. Data are medians of the sum of errors for the four crossings obtained $24 \mathrm{~h}$ before $(-24)$ and 24 and $72 \mathrm{~h}$ after the treatment. ${ }^{*} \mathrm{p}<0.05$, Friedman test and Dunn test (in relation to $-24 \mathrm{~h}$ group).

The first exposure of the animal to the device has a sharper emotional component than the remaining agents of exposure (Moniz et al., 1994; Batatinha et al., 1995; Massoco et al., 1995). This method provides a direct behavioral observation and is very much used in psycho-pharmacology studies of animals, because it is simple and is available for a fast and easy measure of the several behaviors that can be clearly defined. The general activity measured in the open field can be useful to define the doses, administration ways and the latency to the effect of a chemical substance to be studied.

Locomotion by the rat in an open field is inversely associated with anxiety ratings, depending upon whether the locomotion appears purposeful and whether the animal exhibits other exploratory behaviors such as rearing or approaching the center of the open field, in contrast to exhibiting anxiety-related behaviors such as hesitant locomotion, freezing, shivering, and defecation
(Dishman et al., 1996). As the GABAergic drugs are ansiolitcs, the rats of this study that received 0.2 or $20 \mathrm{mg} / \mathrm{kg}$ of MXD and were observed $72 \mathrm{~h}$ after the injections, showed significant reduction of immobility when compared with the rats of control group, and a loss of anxiety was noticed. The lack of effect of $2.0 \mathrm{mg} / \mathrm{kg}$ of MXD may be due to biphasic action of GABAergic drugs (Lloyd and Morselli, 1987; Car and Wisniewski, 1998; Silva et al., 2005).

In this experiment, just a few of significant alterations were detected after the drug administration. This indicated that, even in high doses, MXD did not modify the rat's exploration behaviors in the open field, showing just a weak motor inhibition effect. On the other hand, MDX was able to impair the motor coordination of the animals observed at the wooden beam.

The animal's immobility in the open field and the impairment of motor coordination presented an 
inversed-U-shape profile $72 \mathrm{~h}$ after the treatments, and not in the classical dose-response curve. It is possible that both facts expressed the motor impairment induced by MXD. Additionally, even in a therapeutic dose widely used clinically in different animal species, the motor incoordination was observed.

It is well established that most neurons located within the striatum are GABAergic. The firing pattern of nigral dopaminergic neurons would be modulated differentially by disinhibition of $\mathrm{GABA}_{\mathrm{A}}$ inputs arising from substantia nigra pars reticulata and disinhibition of pallidonigral GABAergic inputs mediated by $\mathrm{GABA}_{\mathrm{B}}$ receptors (Tepper et al., 1995). Tegnér et al. (1993) observed that in the lamprey brain stem-spinal cord, a model system to study how the neuronal networks controlling motor behavior in vertebrates, both receptors, $\mathrm{GABA}_{\mathrm{A}}$ and $\mathrm{GABA}_{\mathrm{B}}$, showed a modulator role, i.e, they acted together in the coordination of the locomotion. Kriem et al. (1998) found that GABAergic transmission in the substantia nigra pars reticulata (SNR), and not in the substantia nigra pars compacta (SNC), would play a crucial role in the control of motor activity of rats exposed to high pressure, and the $\mathrm{GABA}_{\mathrm{A}}$ and $\mathrm{GABA}_{\mathrm{B}}$ receptors, in SNR, had an opposite role in the regulation of the movements. It has been shown that both the receptors, $\mathrm{GABA}_{\mathrm{A}}$ and $\mathrm{GABA}_{\mathrm{B}}$, have a modulator role in the control of locomotion, and they have an opposite roles in the regulation of this behavior (Tegnér et al., 1993; Kriem et al., 1998). It is also known that the stimulation of $\mathrm{GABA}_{\mathrm{B}}$ receptor reduces the locomotor activity and $\mathrm{GABA}_{\mathrm{A}}$ receptor is not involved in the locomotion-reducing effect (Agmo and Giordano, 1985; Paredes et al., 1997). The effective doses of some GABAergic drugs that impair motor execution, reduce ambulatory activity and frequently also motor coordination, as evaluated by open field activity and a treadmill test (Dishman et al., 1996). The present results showing a significant decrease on striatal dopaminergic system activity suggested that MXD should activate the GABAergic system, resulting in a reduced motor coordination in consequence of inhibition of striatal dopamine release. In fact, not only the dopamine levels were decreased but also its metabolite levels, the HVA.

\section{ACKNOWLEDGEMENTS}

This work is part of MS thesis presented by the first author to the Institute of Psychology, University of São Paulo, and was supported by a grant from Conselho Nacional de Desenvolvimento Científico e Tecnológico (CNPq).

\section{RESUMO}

A moxidectina (MXD) é uma droga antiparasitária amplamente empregada em animais domésticos; seu mecanismo de ação, em mamíferos, envolve o neurotransmissor ácido gama-aminobutírico (GABA). Esse neurotransmissor tem papel importante na função motora. Assim, no presente trabalho estudaram-se os efeitos da MXD em alguns parâmetros comportamentais ligados a função motora de ratos e também em sistemas de neurotransmissão central. A atividade geral no campo aberto e a coordenação motora na trave elevada foram empregadas para avaliar os efeitos de diferentes doses de MXD. Os resultados mostraram que: no campo aberto, mesmo as doses maiores ( 2.0 e $20.0 \mathrm{mg} / \mathrm{kg}$ ) de MXD não alteraram as freqüências de locomoção e levantar. Por outro lado, a MXD foi capaz de prejudicar a coordenação motora dos animais avaliada na trave elevada. Estudos neuroquímicos dos níveis estriatais de GABA e dopamina mostraram redução dos níveis de dopamina e seu metabólito, ácido homavanílico, sem interferência nos níveis de GABA estriatal. Considerando que a estimulação de receptores GABAérgicos tem efeito inibidor sobre o sistema dopaminérgico estriatal, nós atribuímos a redução na coordenação motora a ação da MXD sobre o sistema dopaminérgico via ativação do GABA.

\section{REFERENCES}

Agmo, A. and Giordano, M., (1985), The locomotorreducing effects of gabaergic drugs do not depend on the $\mathrm{GABA}_{\mathrm{A}}$ receptor, Psychopharmacology, 87, 5154. 
Arena, J.P., (1994), Expression of Caenorhabditis elegans mRNA in Xenopus oocytes: a model system to study the mechanism of action of avermectins, Parasitology Today, 10, 35-37.

Arena, J.P., Liu, K.K., Paress, P.S. and Cully, D.F., (1991), Avermectin-sensitive chloride currents induced by Caenorhabditis elegans RNA in Xenopus oocytes, Molecular Pharmacology, 40, 368-374.

Arena, J.P., Liu, K.K., Paress, P.S., Frazier, E, Cully, D.F., Mrozik, H. and Schaeffer, J.M., (1995), The mechanism of action of avermectin in Caenorhabditis elegans: correlation between activation of glutamatesensitive chloride current, membrane binding and biological activity, Journal of Parasitology, 81, 286294.

Arena, J.P., Liu, K.K., Paress, P.S., Schaeffer, J.M. and Cully, D.F., (1992), Expression of glutamateactivated chloride current in Xenopus oocytes injected with Caenorhabditis elegans RNA: evidence for modulation by avermectin, Molecular Brain Research, 15, 339-348.

Batatinha, M.J.M., Spinosa, H.S. and Bernardi, M.M., (1995), Croton zehntneri: possible central nervous system effects of the essential oil in rodents. Journal of Ethnopharmacology, 45, 53-57.

Campbell, W.C., (1989), Ivermectin and Abamectin, (Springer-Verlag, New York).

Car, H., Wisniewski, K.,(1998) The effect of baclofen and AP-7 on selected behavior in rats, Pharmacology Biochemistry and Behavior, 59 (3), 685-689.

Cleland, T.A., (1996), Inhibitory glutamate receptor channels, Molecular Neurobiology, 13, 97-136.

Cully, D.F., Wilkinson, H., Vassilatis, D.K., Etter, A. and Arena, J.P., (1996), Molecular biology and eletrophysiology of glutamate-gated chloride channels of invertebrates, Parasitology, 113, 191200, Sup.

Dawson, G.R., Wafford, K.A., Smith, A., Marshall, G.R., Bayley, P.J., Schaeffer, J.M., Meinke, P.T. and Mckernan, R.M., (2000), Anticonvulsant and adverse effects of avermectin analogs in mice are mediated through the gama-aminobutyric $\operatorname{acid}_{\mathrm{a}}$ receptor, Journal of Pharmacology and Experimental Therapeutics, 295(3), 151-160.

Dishman, R.K., Dunn, A.L., Youngstedt, S.D., Davis, J.M., Burgess, M.L., Wilson, S.P. and Wilson, M.A., (1996), Increase open field locomotion and decreased striatal $\mathrm{GABA}_{\mathrm{A}}$ binding after activity wheel running. Physiology and Behavior, 60(3), 699-705.

Duce, I.R. and Scott, R.H., 1985. Actions of hydroavermectin $\mathrm{B}_{1 \mathrm{a}}$ on insect muscle. Britsh Journal of Pharmacology, 85, 395-401.

Felício, L. F., Flório, J. C., Sider, L. H., Cruz-Casallas, P. E.; Bridges, R.S., (1996), Reproductive experience increases striatal and hypothalamic dopamine levels in pregnant rats. Brain Research Bulletin, 40(4), 253256.
Feng, X.P., Hayashi, J., Beech, R.N. and Prichard, R.K., (2002), Study of the nematode putative GABA type-A receptor subunits: evidence for modulation by ivermectin. Journal of Neurochemistry, 83, 870-878.

Fisher, M.H. and Mrozik, H., (1989), Chemistry. In: Campbell, W.C., Ivermectin and Abamectin, (Springer-Verlag, New York), 1-23.

Forrester, S.G., Prichard, R.K. and Beech, R.N., (2002), A glutamate-gated chloride channel subunit from Haemonchus contortus: expression in a mammalian cell line, ligand binding, and modulation of anthelmintic binding by glutamate. Biochemical Pharmacology, 63, 161-168.

Jeffery, N.D. and Blakemore, W.F., (1997), Locomotor deficits induced by experimental spinal cord demyelination are abolished by spontaneous remyelination. Brain, 120, 27-37.

Joint FAO / WHO Expert Committee on Food Additives, 45 ${ }^{\circ}$, Genebra, Sw, 1995. Evaluation of certain Veterinary Drug Residues in Food. Genebra, (1995), 15-21. WHO Technical Report Series, 864.

Kriem, B., Cagniard, B., Bouquet, C., Rostain, J.C. and Abraini, J.H., (1998), Modulation by GABA transmission in the substantia nigra compacta and reticulata of locomotor activity in rats exposed to high pressure. Neuropharmacology and Neurotoxicology, 9, 1343-1347.

Lanusse, C., Lifschitz, A., Virkel, G., Alvarez, L., Sánchez, S., Sutra, J.F., Gaultier, P. and Alvinerie, M., (1997), Comparative plasma disposition kinetics of ivermectin, moxidectin and doramectin in cattle, Journal of Veterinary Pharmacology and Therapeutics, 20, 91-99.

Lifschitz, A., Virkel, G., Sallovitz, J., Imperiale, F., Pis, A. and Lanusse, C., (2002), Loperamide-induced enhancement of moxidectin availability in cattle, Journal of Veterinary Pharmacology and Therapeutics, 25, 111-120.

Lloyd, K.G, Morselli, P.L., (1987) Psychopharmacology of GABAergic drugs. In: Meltzer, H.Y., ed. Psychopharmacology. The third generation of progress, (Raven Press, New York), 183-195.

Massoco, C.O., Silva, M.R.P., Gorniak, S.L., Spinosa, H.S. and Bernardi, M.M., (1995), Behavioral effects of long term administration of catnip (Nepeta cataria) in mice, Veterinary and Human Toxicology, 37(6), 530-533.

Molento, M.B., Lifschitz, A., Sallovitz, J., Lanusse, C. and Prichard, R.K., (2004), Influence of verapamil on the pharmacokinectics of the antiparasitic drugs ivermectin and moxidectin in sheep, Parasitology Research, 92, 121-127.

Moniz, A.C., Bernardi, M.M. and Spinosa, H.S., (1994), Effects of a pyrethroid type ii pesticide on conditioned behaviors of rats, Veterinary and Human Toxicology, 36 (2), 120-124. 
Nissbrandt, H. and Engberg, G., (1996), The GABA ${ }^{-}$ receptor antagonist, CGP 35348, antagonises $\gamma$ hydroxybutyrate- and baclofen-induced alterations in locomotor activity and forebrain dopamine levels in mice, Journal of Neural Transmission, 103, 12551263.

Njue, A.I., Hayashi, J., Kinne, L., Feng, X.P. and Prichard, R.K., (2004), Mutations in the extracellular domains of glutamate-gated chloride channel $\alpha 3$ and $\beta$ subunits from ivermectin-resistant Cooperia oncophora affect agonist sensitivity, Journal of Neurochemistry, 89, 1137-1147.

Paredes, R.G., Karam, P., Highland, L., and Agmo, A., (1997), GABAergic drugs and socio-sexual behavior, Pharmacology, Biochemistry and Behavior, 58(2), 291-298.

Roder, J.D., (1998), An overview of ivermectin toxicosis, Veterinary and Human Toxicology, 40(6), 369-370.

Schaeffer, J.M. and Haines, H.W., (1989), Avermectin binding in Caenorhabditis elegans. a two-state model for the avermectin binding site, Biochemical Pharmacology, 38, 2329-2338.

Shoop, W.L., Mrozik, H. and Fisher, M.H., (1995), Structure and activity of avermectins and milbemycins in animal health, Veterinary Parasitology, 59, 139-156.

Silva, M.R.P., Oliveira, C.A., Felicio, L.F., Nasello, A.G., Bernardi, M.M., (1998). Perinatal treatment with picrotoxin induces sexual, behavioral, and neuroendocrine changes in male rats Pharmacology Biochemistry and Behavior, 60(1), 203-208.

Spinosa, H.S., Generutti, M. and Bernardi, M.M., (1999), Anxiolytic and anticonvulsant properties of doramectin in rats: behavioral and neurochemistry evaluations, Comparative Biochemistry and Physiology. C, 127, 359-366.

Spinosa, H.S., Stilck, S.R.A.N. and Bernardi, M.M., (2002), Possible anxiolytic effects of ivermectin in rats, Veterinary Research Communications, 26, 309321.
Steel, J.W., (1993). Pharmacokinectics and metabolism of avermectins in livestock, Veterinary Parasitology, 48, 45-57.

Takiguchi, Y., Mishima, H., Okuda, M., Terao, M., Aoki, A. and Fukuda, R., (1980), Milbemycins, a new family of macrolide antibiotics: fermentation, isolation and physico-chemical properties, Journal of Antibiotics, 33(10), 1120-1127.

Tegnér, J., Matsushima, T., El Manira, A., and Grillner, S., (1993), The spinal GABA system modulates burst frequency and intersegmental coordination in the lamprey. differential effects of $\mathrm{GABA}_{\mathrm{A}}$ and $\mathrm{GABA}_{\mathrm{B}}$ receptors, Journal of Neurophysiology, 69(3), 647656.

Tepper, J.M., Martin, L.P. Anderson, D.R., (1995), GABAa receptor-mediated inhibition of rat substantia nigra dopaminergic neurons by pars reticulata projection neurons. Journal of Neuroscience, 15(4), 3092-3103.

Turner, M.J. and Schaeffer, J.M., (1989), Mode of the action of ivermectin, In: Campbell, W.C., Ivermectin and Abamectin, (Springer-Verlag, New York), 73-88.

Wolstenholme, A.J., (1997), Glutamate-gated chloride channels in Caenorhabditis elegans and parasitic nematodes, Biochemical Society Transactions, 25, 830-834.
Received: March 16, 2006; Revised: September 23, 2006; Accepted: October 23, 2008 